\title{
Evaluation of morphological characteristics, yield and nutritive value of Brachiaria grass ecotypes in northwestern Ethiopia
}

Wubetie Adnew Wassie ${ }^{1 *}\left(\mathbb{0}\right.$, Berhanu Abraha Tsegay ${ }^{1}$, Asaminew Tassew Wolde $^{2}$ and Bimrew Asmare Limeneh ${ }^{2}$

\begin{abstract}
Background: A study was conducted to evaluate the effect of altitude and harvesting dates on productivity and nutritive value of three Brachiaria brizantha grass ecotypes (Eth. 13726, Eth. 13809 and Eth. 1377) in northwestern Ethiopia. A factorial arrangement of treatments was employed with a combination of three altitudes and three harvesting dates. The data collected consisted of plant height (PH), number of tillers, number and length of leaves and fresh yield. The yield and chemical analysis of forage samples were analyzed for dry matter yield, ash, crude protein (CP), neutral detergent fiber (NDF), acid detergent fiber (ADF) and acid detergent lignin. All data were subjected to analysis of variance procedures, with significance tested at $P<0.05$.
\end{abstract}

Results: Results indicated that the highest plant height (PH) was recorded in all sites (low, mid- and high altitudes) by Eth. 1377 ecotype followed by Eth. 13726 ecotype (low and mid-altitudes) and in high altitude by Eth. 13809 ecotype. The highest DM yield was recorded by Eth. 13809 ecotype (7.26, 5.98 and 4.50) which was followed by Eth. 1377 ecotype $(6.28,4.68$ and 4.30$)$ at low, mid- and high altitudes, respectively. There was significant difference $(P>0.05)$ in DM yield with increasing harvesting dates for all ecotypes. CP content declined with increased harvesting date in all ecotypes [Eth. 13726 (16.33, 10.63 and 6.72), Eth. 13809 (13.87, 10.60 and 9.57) and Eth. 1377 (14.80, 10.15 and 7.86)] for 60, 90 and 120 harvesting dates, respectively. All ecotypes had the highest CP content at day 60 harvesting stage.

Conclusions: Although all ecotypes had potential as an alternative ruminant feed in all altitude areas in Ethiopia, highest CP and lowest NDF and ADF concentrations were recorded by Eth13809 ecotype. Its capability to grow at low rainfall maintaining high yields is an additional advantage over the other two. Thus, among the tested ecotype grasses Eth13809 showed outstanding potential as a forage plant especially in low altitude area of northwestern Ethiopia.

Keywords: Dry matter yield, Grass ecotypes, Plant height, Tiller number

\section{Background}

Livestock production is one of the most important agricultural land use systems in the world, with grasslands covering $25 \%$ of land surface and contributing to the livelihoods of more than 800 million people [52]. However, in Ethiopia livestock production has been mainly constrained by inadequate supply and poor quality of

\footnotetext{
*Correspondence: wu1999as@yahoo.com

${ }^{1}$ Department of Biology, College of Science, Bahir Dar University, P. O. Box 76, Bahir Dar, Ethiopia

Full list of author information is available at the end of the article
}

available feed resources $[18,21])$. This could be further emphasized by the fact that feed accounts for $60-70 \%$ of the costs associated with livestock production.

Nowadays, the most important livestock feed resources in Ethiopia are natural pasture, crop residues and grass hay [1]. Natural pasture hay and crop residues which provide the bulk livestock feed in Ethiopia are seasonally produced during particular periods of the year (October-January) following the main rainy season. Excess forage production is experienced during the rainy season, but more often, acute shortages occur in the dry season

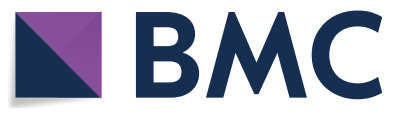

(c) The Author(s) 2018. This article is distributed under the terms of the Creative Commons Attribution 4.0 International License (http://creativecommons.org/licenses/by/4.0/), which permits unrestricted use, distribution, and reproduction in any medium, provided you give appropriate credit to the original author(s) and the source, provide a link to the Creative Commons license, and indicate if changes were made. The Creative Commons Public Domain Dedication waiver (http://creativecommons.org/ publicdomain/zero/1.0/) applies to the data made available in this article, unless otherwise stated. 
as observed in some parts of the country [2]. According to CSA [14] report, the major feed resources in the country are green fodder $(54.59 \%)$, crop residue $(31.6 \%)$, hay $(6.81 \%)$ and agricultural by product $(1.53 \%)$ which have poor quality. Common forage crops adapted in the farming systems in Ethiopia like Napier grass (Pennisetum sp.) and silver leaf Desmodium sp. have been affected by the global effects of climate change and Napier grass is also threatened by the emergence of stunt and smut diseases [37], which has also limited its expansion to drier areas. Consequently, finding alternative feeds for livestock is an important step to sustain livestock production in the country. This constraint can be solved through finding a climate-friendly way through the introduction of improved forage varieties of the Brachiaria genus [50]. Moreover, climate smart agriculture is one of the means that can help to reduce greenhouse gas emissions and increase livestock productivity of the country through improved livestock feed and feeding practices [19]. Brachiaria grasses tend to be drought resistant and resilient in infertile soils, and produce well with relatively low levels of fertilizer inputs. They are also resistant to many diseases affecting baseline varieties in Eastern Africa, particularly Napier stunt and smut disease [22, 31]. Thus, as a new strategy termed using 'climate smart Brachiaria grass', which can withstand heavy grazing is best option.

In addition to adapted to drought, diseases and lowfertility soils, Brachiaria grass sequesters carbon through its large roots system enhance nitrogen use efficiency and subsequently minimize eutrophication and greenhouse gas emissions [6, 36]. Brachiaria grass plays important roles in soil erosion control and ecological restoration. Brachiaria grass species have been important component of sown pastures in humid low lands and savannas of tropical America with current estimated acreage of 99 million hectare in Brazil alone [25]. Moreover, the grass has a potential of production of high dry matter yield [49]. Additional advantages of using the Brachiaria genus in the integrated systems are that the species produce abundant roots which contribute to the collection of water, soil aggregation and aeration [27].

The genus Brachiaria consists of roughly 100 species which grow in the tropics and subtropics. Most of these species are native to Africa, where they constitute important components of the natural savanna landscape [22]. We see the distribution of B. brizantha is high in Africa including Ethiopia [15] and need more research to exploit maximum in the region. Recent trials indicate that adoption of $B$. brizantha cultivars has the potential to increase baseline milk production of 3-5 L/cow/d on participating farms in Kenya by $15-40 \%$ [50]. A farm trial in Rwanda reported a 30\% increase in milk production and a $20 \%$ increase in meat production [13]. Despite the diversity of Brachiaria spp. in Eastern and Central Africa, comparatively little information is available on their agro-morphological characteristics, yield and chemical composition.

The productivity of the different grass species could be distinctly different and is also influenced by area of origin, including temperature, light intensity, total rainfall, soil type, fertilization level, and by stage of maturity [24, 26]. In East Africa, Bogdan [11] reported that B. brizantha is very variable and several varieties show striking differences in habit, morphology and seed setting capacity. It is possible that the different varieties will perform differently in different ecological zones, but information of this kind is lacking in Ethiopia. B. brizantha grass growing in Ethiopia is the wild type and ecologically different (an ecotype) from that in other countries, which is not developed/enriched like that of other countries such as Brazil. Therefore, the study was aimed to evaluate the performance of $B$. brizantha ecotypes and to select the best herbage yielding and quality among selected three ecotypes so as to use the better performing ecotype for wider distribution among livestock producer communities in the country.

\section{Materials and methods \\ Description of the study areas}

The study was conducted in south Gondar (Amhara Regional State) at three agro-ecologies using a rain fed system. The low altitude area was represented by a location called Futan at Tach Gayint district located at $11^{\circ} 22^{\prime} \mathrm{N}$ and $28^{\circ} 19^{\prime} \mathrm{E}$ at an altitude of $1230 \mathrm{~m}$ above sea level. Mean minimum and maximum annual temperature of the district ranges from 13 to $27^{\circ} \mathrm{C}$ and the mean minimum and maximum annual rainfall ranges from 900 to $1000 \mathrm{~mm}$ per annum. The mid-altitude location was represented by a place called Woreta at Fogera district which is situated at $11^{\circ} 58^{\prime} \mathrm{N}$ and $37^{\circ} 41^{\prime} \mathrm{E}$ at an altitude range of 1774 masl and is predominantly classified as mid-altitude agro-ecology. The mean annual rainfall is $1216.3 \mathrm{~mm}$ and ranges from 1103 to $1336 \mathrm{~mm}$. According to the district Office of Agriculture, the dominant soil type is black clay (ferric vertisols) (personal communication). The highland area was represented by Farta district, Tsegure Eyesus Kebele (Kebele is the smallest administration unit in Ethiopia) at a site called Melo located near Debre Tabor Town, at $11^{\circ} 11^{\prime} \mathrm{N}$ and $38^{\circ} \mathrm{E}$ and at an altitude of $2650 \mathrm{~m}$ above sea level. The soils of Melo site are characterized by clay and sand mixture with chemical composition of $2.26 \%$ organic matter, $0.11 \%$ total nitrogen and $\mathrm{pH}$ of 5.47 . The mean annual rainfall is about $1570 \mathrm{~mm}$ and the mean maximum and 
minimum annual temperatures were reported to be $21.5 \mathrm{C}$ and $9.6 \mathrm{C}$, respectively.

\section{Land preparation, planting and experimental design}

A total area of $341 \mathrm{~m}^{2}$ was prepared for each location. The experimental land was plowed in May and harrowed in June 2017. The land was divided into three blocks each of which comprised three plots (3*3 m each). Planting materials Brachiaria brizantha ecotypes/wild (Eth. 13726, Eth. 13809 and Eth. 1377) were collect from International Livestock Research Institute (ILRI) Forage Gene Bank Addis Ababa, Ethiopia. The ecotypes were planted using vegetative root splits in rows. The experiment was laid out in a factorial arrangement of three altitudes (low, mid and high) and three harvesting stages (60 days, 90 days and 120 days) in a randomized complete block design with three replications. The spacing between rows and plants was $50 \mathrm{~cm}$ and $30 \mathrm{~cm}$, respectively. Land preparation, planting, weeding, harvesting and related management practices were applied according to standard practice for the grass [42]. Artificial fertilizers (di-ammonium phosphate and urea) were applied at rate of $100 \mathrm{~kg} / \mathrm{ha}$ and urea at $25 \mathrm{~kg} / \mathrm{ha}$ during planting and after establishment based on the recommendations for the grass.

\section{Data collection}

Morphological parameters such as plant height and leaf length were measured from 10 plants that were randomly selected from middle rows of each plot at 60 days, 90 days and 120 days after planting. The number of tillers and leaves was computed as mean counts. To determine biomass yield, the forage harvesting was done by hand using a sickle leaving a stubble height of $8 \mathrm{~cm}$ according to recommended practice. The fresh herbage yield was measured immediately after each harvest using a portable balance with a sensitivity of $0.01 \mathrm{~g}$. Representative samples were taken from each plot at each site and were dried in a draft oven at $65^{\circ} \mathrm{C}$ for $72 \mathrm{~h}$ before chemical analysis.

\section{Chemical analyses}

The chemical composition of all samples of feeds collected during agronomic was conducted at Debre Berhan Agricultural Research Center Animal Nutrition Laboratory. The grass samples were dried at $65^{\circ} \mathrm{C}$ for $72 \mathrm{~h}$ and ground to pass through a $1 \mathrm{~mm}$ sieve. Ash/organic matter $(\mathrm{OM})$, dry mater $(\mathrm{DM})$, crude protein and total ash were determined according to AOAC (1990). The neutral detergent fibers (NDF), acid detergent fiber (ADF), acid detergent lignin (ADL) were determined according to Van Soest and Robertson [55]. The CP was calculated as percentage of nitrogen in the sample multiplied by a factor of 6.25 .

\section{Data analysis}

The collected data were analyzed using general linear model of statistical analysis system (SAS) procedures of 2002 version 9.0. Least significant difference (LSD) test was employed for variables whose $F$ values declared a significant difference $(P<0.05)$. The statistical model for data analysis was:

$$
\begin{aligned}
Y i j k= & \mu+A i+H j+C k+A i * H j++A * C \\
& +H * C+\varepsilon i j k
\end{aligned}
$$

where Yijk is the response (plant morphological parameters, chemical composition, and yield of B. brizanthagrass) at each altitude and harvesting days

$$
\mu=\text { overall mean, }
$$$$
A i=\text { altitude (i }=\text { low, mid and high), }
$$$$
H j=\text { effect of harvesting days }(\mathrm{j}=60,90 \text {, and } 120 \text { days })
$$$$
C k=\text { Brachiaria brizantha Ecotypes (Eth. 13726, Eth. }
$$
13809 and Eth. 1377).

$A i^{*} H j=$ the interaction of ith altitude and jth harvesting date.

$A^{*} C=$ interaction of altitude and cultivars.

$H^{*} \mathrm{C}=$ interaction of harvesting date and cultivars.

$\varepsilon i j k=$ the residual error.

\section{Results}

\section{Effect of harvesting dates and altitudes on plant} morphological characteristics of $B$. brizantha ecotypes

The results of the effect of harvesting dates and altitudes on plant morphological characteristics of Eth. 13726, Eth. 13809 and Eth. 1377 grass ecotypes are presented in Table 1 . The overall results obtained in the three agro-ecologies indicate that all morphological characteristics of Eth. 13726 grass studied were significantly affected $(P>0.05)$ by harvesting dates and altitude. In mid-altitude, plant height (PH), number of tillers per plant (NTPP), number of leaves per plant (NLPP) and length of leaves per plant (LLPP) showed significant difference $(P<0.05)$ while between low and high altitude there was significant difference $(P<0.05)$ in $\mathrm{PH}$ only. All parameters were significantly $(P<0.05)$ increased as harvesting stage increases from 60 to 120 days. Plant height showed high increment at day 90 while NLPP showed significant increment $(P>0.05)$ by harvesting at day 120. Although there was no significant $(P<0.05)$ difference in $\mathrm{PH}$ between second and third harvest, numerically there were high increment in NLPP.

The overall results obtained in the three agro-ecologies indicate that with the exception of $\mathrm{PH}$ by altitudes, other morphological characteristics of Eth. 13809 grass studied were significantly affected $(P>0.05)$ by altitude and harvesting date. Except NLPP by altitude, all the morphological characteristics (PH, NTPP, NTPP and LLPP) of Eth. 1377 grass in all studied agro-ecology were significantly affected $(P>0.05)$ by altitude and harvesting date. 
Table 1 Effects of altitude, harvesting stages and their interactions on plant morphological characteristics of brizantha grass ecotypes

\begin{tabular}{|c|c|c|c|c|}
\hline \multirow{2}{*}{$\begin{array}{l}\text { Factors } \\
\text { Cultivars }\end{array}$} & \multicolumn{4}{|c|}{ Parameters } \\
\hline & $\mathrm{PH}(\mathrm{cm})$ & NTPP (counts) & NLPP (counts) & $\operatorname{LLPP}(\mathrm{cm})$ \\
\hline \multicolumn{5}{|c|}{ Eth. 13726} \\
\hline \multicolumn{5}{|l|}{ Altitude } \\
\hline Low & $59.39^{a}$ & $24.71^{\mathrm{ab}}$ & $4.64^{b}$ & $18.61^{\mathrm{ab}}$ \\
\hline Mid & $56.97^{a}$ & $33.67^{\mathrm{a}}$ & $5.51^{\mathrm{a}}$ & $19.38^{\mathrm{a}}$ \\
\hline High & $36.86^{b}$ & $20.67^{b}$ & $4.08^{b}$ & $13.89^{b}$ \\
\hline Sig & $* *$ & * & $* *$ & $*$ \\
\hline \multicolumn{5}{|c|}{ Harvesting stages } \\
\hline 60 & $26.69^{b}$ & $17.89^{\mathrm{b}}$ & $3.97^{b}$ & $14.29^{b}$ \\
\hline 90 & $56.83^{\mathrm{a}}$ & $25.07^{\mathrm{ab}}$ & $4.58^{b}$ & $17.23^{\mathrm{ab}}$ \\
\hline 120 & $69.69^{a}$ & $36.09^{a}$ & $5.69^{\mathrm{a}}$ & $20.36^{\mathrm{a}}$ \\
\hline Mean & 51.07 & 26.35 & 4.74 & 17.29 \\
\hline SE & 7.39 & 3.40 & 0.33 & 1.29 \\
\hline Sig & $* * *$ & * & $* *$ & $*$ \\
\hline \multicolumn{5}{|l|}{ Eth. 13809} \\
\hline \multicolumn{5}{|l|}{ Altitude } \\
\hline Low & 56.40 & $35.77^{\mathrm{a}}$ & $4.77^{\mathrm{a}}$ & $20.17^{b}$ \\
\hline Mid & 52.99 & $35.07^{\mathrm{a}}$ & $4.52^{\mathrm{a}}$ & $23.89^{\mathrm{a}}$ \\
\hline High & 45.03 & $29.72^{b}$ & $3.78^{b}$ & $16.27^{c}$ \\
\hline Sig & NS & $*$ & * & $* *$ \\
\hline \multicolumn{5}{|c|}{ Harvesting stages } \\
\hline 60 & $33.14^{b}$ & $25.13^{b}$ & $3.62 b$ & $17.52^{b}$ \\
\hline 90 & $53.01^{\mathrm{a}}$ & $29.86^{b}$ & $4.29 b$ & $19.84^{\mathrm{ab}}$ \\
\hline 120 & $68.27^{\mathrm{a}}$ & $45.56^{a}$ & $5.16 a$ & $22.97^{b}$ \\
\hline Mean & 51.47 & 33.52 & 4.36 & 20.11 \\
\hline SE & 5.52 & 3.26 & 0.27 & 1.38 \\
\hline Sig & $* *$ & $* * *$ & $* *$ & $*$ \\
\hline \multicolumn{5}{|l|}{ Eth. 1377} \\
\hline \multicolumn{5}{|l|}{ Altitude } \\
\hline Low & $65.72^{\mathrm{a}}$ & $25.09^{b}$ & 5.48 & $18.01^{\mathrm{a}}$ \\
\hline Mid & $62.91^{\mathrm{a}}$ & $32.14^{\mathrm{a}}$ & 5.07 & $17.39^{\mathrm{a}}$ \\
\hline High & $47.57^{b}$ & $30.93^{\mathrm{a}}$ & 4.48 & $13.25^{b}$ \\
\hline Sig & $* *$ & $* *$ & NS & $* *$ \\
\hline \multicolumn{5}{|c|}{ Harvesting stages } \\
\hline 60 & $47.89^{c}$ & $18.54^{c}$ & $3.80^{b}$ & $12.97^{c}$ \\
\hline 90 & $58.75^{b}$ & $26.36^{b}$ & $4.84^{\mathrm{ab}}$ & $16.72^{b}$ \\
\hline 120 & $69.56^{\mathrm{a}}$ & $43.25^{\mathrm{a}}$ & $6.39^{a}$ & $18.96^{\mathrm{a}}$ \\
\hline Mean & 58.73 & 29.38 & 5.01 & 16.22 \\
\hline SE & 4.29 & 3.83 & 0.44 & 1.16 \\
\hline Sig & $* *$ & $* * *$ & $*$ & $* * *$ \\
\hline
\end{tabular}

Treatments means with different letters in a column are significantly different $(P<0.05)$ for altitudes and harvesting stages. NS for non-significant, ${ }^{*}$ for $P<0.05$ (5\%), **for $P<0.01(1 \%)$ and $* * *$ for $P<0.001(0.1 \%)$; SE standard error, $P H$ plant height, NTPP number of tillers per plant, LLPP leaf length per plant
Effect of cutting ages and altitudes on chemical composition, dry matter yield of three $B$. brizantha grass ecotypes

The effect of harvesting dates and altitudes on chemical composition, dry matter yield (DMY) and crude protein yield (CPY) of Eth. 13726, Eth. 13809 and Eth. 1377 grasses is shown in Table 2. The effect of harvesting date and altitude on chemical composition, DMY and CPY of Eth. 13726 grass is shown in Table 2. DM, DMY and CP, NDF and ADF by harvesting date and only DM by altitude showed significant differences $(P<0.05)$ in Eth. 13726 grass.

There were significant differences $(P<0.05)$ in DM, DMY, $\mathrm{CP}$ and $\mathrm{CPY}$ both by altitude and harvesting date. However, there was no significant difference $(P<0.05)$ between midand high altitudes. Moreover, there were significant differences $(P<0.05)$ in ash by altitude and ADF by harvesting date of Eth. 13809. The overall results of the grass in low altitude show that greatest DM, DMY, ASH, CP and CPY than mid- and high altitudes. There were significant differences $(P<0.05)$ in DM and DMY by altitude and harvesting date. $\mathrm{CPY}$ by altitude and $\mathrm{CP}, \mathrm{ADF}$ and $\mathrm{ADL}$ by harvesting dates were also significantly different $(P<0.05)$ in Eth. 1377 grass.

\section{Chemical composition of three Brachiaria grass lines}

The effect of altitude, harvesting date and their interaction on chemical composition of Brachiaria grasses is shown in Table 3 . There were highly significant difference $(P<0.05)$ in the average DM, DMY, CPY, ADF and ADL of the three ecotypes. Except NDF, ADF and ADL by attitudes and ash by harvesting dates, there were highly significant $(P<0.05)$ effects of altitude and harvesting date between ecotypes and have also high interactions between ecotypes and altitudes. There were significant $(P<0.05)$ overall interactions except for NDF.

\section{Agronomic performance of three B. brizantha ecotypes grass lines}

The agronomic comparison of three ecotype grasses (Eth. 13726, Eth.13809 and Eth.1377) is presented in Table 4. Except NLPP, the agronomic performances of PH, NTPP and LLPP differ significantly $(P>0.05)$ between three Brachiaria grass lines. Eth. 1377 performs best in $\mathrm{PH}$ and NLPP from the other two ecotypes while in case of NTPP and LLPP Eth. 13809 showed best performance.

\section{Discussion}

The agronomic characteristics result indicated that all ecotypes tested recorded higher PH than other Brachiaria grass cultivars (Llanero, MG4, Marandu, Piata, Mulato 
Table 2 Effect of altitude, cutting age and their interaction on chemical composition and yield of Bracheria grass ecotypes

\begin{tabular}{|c|c|c|c|c|c|c|c|c|}
\hline \multirow{2}{*}{$\begin{array}{l}\text { Factors } \\
\text { Cultivar }\end{array}$} & \multicolumn{8}{|c|}{ Parameters } \\
\hline & DM (\%) & DMY (t/ha) & Ash (\%) & CP (\%) & CPY (t/ha) & NDF (\%) & ADF (\%) & ADL (\%) \\
\hline \multicolumn{9}{|c|}{ Eth. 13726} \\
\hline \multicolumn{9}{|l|}{ Altitude } \\
\hline Low & $37.60^{a}$ & 4.24 & 8.97 & 9.81 & 0.33 & 71.70 & 50.99 & 14.46 \\
\hline Mid & $36.55^{b}$ & 4.63 & 9.66 & 12.36 & 0.47 & 67.57 & 51.02 & 16.57 \\
\hline High & $35.99^{b}$ & 3.28 & 13.98 & 11.51 & 0.34 & 69.42 & 50.29 & 14.87 \\
\hline Sig & $* *$ & NS & NS & NS & NS & NS & NS & NS \\
\hline \multicolumn{9}{|c|}{ Harvesting stages } \\
\hline 60 & $35.03^{c}$ & $1.69^{b}$ & 12.67 & $16.33^{\mathrm{a}}$ & 0.29 & $63.87^{\mathrm{b}}$ & $42.14^{b}$ & 11.84 \\
\hline 90 & $36.64^{b}$ & $3.63^{\mathrm{ab}}$ & 10.85 & $10.63^{\mathrm{ab}}$ & 0.42 & $68.72^{\mathrm{ab}}$ & $52.73^{a}$ & 15.37 \\
\hline 120 & $38.47^{\mathrm{a}}$ & $6.83^{\mathrm{a}}$ & 9.10 & $6.72^{b}$ & 0.44 & $76.11^{\mathrm{a}}$ & $57.44^{\mathrm{a}}$ & 18.69 \\
\hline Mean & 36.71 & 4.05 & 10.87 & 11.23 & 0.38 & 69.56 & 50.77 & 15.30 \\
\hline SE & 0.55 & 0.83 & 1.06 & 1.55 & 0.05 & 1.99 & 2.38 & 1.18 \\
\hline Sig & $* *$ & * & NS & * & NS & $*$ & ** & NS \\
\hline \multicolumn{9}{|c|}{ Eth. 13809} \\
\hline \multicolumn{9}{|l|}{ Altitude } \\
\hline Low & $38.77^{\mathrm{a}}$ & $7.26^{\mathrm{a}}$ & $15.40^{\mathrm{a}}$ & $14.93^{\mathrm{a}}$ & $1.04^{\mathrm{a}}$ & 65.26 & 41.85 & 10.64 \\
\hline Mid & $38.13^{b}$ & $5.98^{\mathrm{ab}}$ & $9.15^{b}$ & $10.54^{b}$ & $0.57^{b}$ & 66.85 & 44.96 & 11.99 \\
\hline High & $36.35^{c}$ & $4.50^{b}$ & $12.48^{\mathrm{a}}$ & $8.57^{b}$ & $0.36^{b}$ & 64.31 & 43.60 & 10.75 \\
\hline Sig & $* * *$ & $* *$ & $* *$ & $* *$ & $* *$ & NS & NS & NS \\
\hline \multicolumn{9}{|c|}{ Harvesting stages } \\
\hline 60 & $36.58^{c}$ & $2.95^{c}$ & 12.35 & $13.87^{\mathrm{a}}$ & $0.43^{b}$ & 59.91 & $39.11^{b}$ & $9.12^{\mathrm{b}}$ \\
\hline 90 & $37.70^{b}$ & $6.51^{\mathrm{b}}$ & 11.83 & $10.60^{b}$ & $0.72^{\mathrm{ab}}$ & 63.89 & $42.18^{\mathrm{ab}}$ & $10.54^{\mathrm{ab}}$ \\
\hline 120 & $38.96^{\mathrm{a}}$ & $8.28^{\mathrm{a}}$ & 12.85 & $9.57^{b}$ & $0.83^{\mathrm{a}}$ & 72.62 & $49.11^{\mathrm{a}}$ & $13.72^{\mathrm{a}}$ \\
\hline Mean & 37.75 & 5.91 & 12.34 & 11.35 & 0.66 & 65.47 & 43.47 & 11.13 \\
\hline SE & 0.50 & 0.89 & 0.95 & 1.156 & 0.12 & 2.40 & 1.65 & 0.80 \\
\hline Sig & $* * *$ & $* * *$ & NS & $* *$ & $*$ & NS & $*$ & NS \\
\hline \multicolumn{9}{|l|}{ Eth. 1377} \\
\hline \multicolumn{9}{|l|}{ Altitude } \\
\hline Low & $36.96^{\mathrm{a}}$ & $6.28^{\mathrm{a}}$ & 12.30 & 13.04 & $0.75^{\mathrm{a}}$ & 67.57 & 48.57 & 13.38 \\
\hline Mid & $35.14^{b}$ & $4.68^{b}$ & 11.47 & 11.17 & $0.47^{b}$ & 63.81 & 43.07 & 12.93 \\
\hline High & $35.04^{b}$ & $4.30^{b}$ & 10.03 & 8.60 & $0.34^{b}$ & 71.80 & 48.79 & 13.61 \\
\hline Sig & $* * *$ & $* *$ & NS & NS & * & NS & NS & NS \\
\hline \multicolumn{9}{|c|}{ Harvesting stages } \\
\hline 60 & $34.85^{c}$ & $2.65^{c}$ & 11.58 & $14.80^{\mathrm{a}}$ & 0.41 & 61.01 & $40.70^{b}$ & $9.94^{b}$ \\
\hline 90 & $35.57^{b}$ & $5.72^{b}$ & 9.75 & $10.15^{b}$ & 0.60 & 68.64 & $47.65^{a}$ & $14.28^{a}$ \\
\hline 120 & $36.72^{\mathrm{a}}$ & $6.89^{a}$ & 12.47 & $7.86^{b}$ & 0.54 & 73.52 & $52.08^{\mathrm{a}}$ & $15.70^{\mathrm{a}}$ \\
\hline Mean & 35.71 & 5.09 & 11.27 & 10.94 & 0.52 & 67.72 & 46.81 & 13.31 \\
\hline SE & 0.42 & 0.71 & 0.72 & 1.26 & 0.07 & 2.47 & 1.97 & 0.92 \\
\hline Sig & $* *$ & $* * *$ & NS & $*$ & NS & NS & $* *$ & * \\
\hline
\end{tabular}

$D M$ dry matter, $D M Y$ dry matter yield, $C P$ crude protein, $C P Y$ crude protein yield, NDF neutral detergent fiber, $A D F$ acid detergent fiber, $A D L$ acid detergent lignin, $S E$ standard error, CV coefficient of variation

Mean values followed by a different lowercase superscript letter in the same column are statistically significant at $P<0.05$. NS for non-significant, ${ }^{*}$ for $P<0.05$ (5\%), ${ }^{* *}$ for $P<0.01$ (1\%) and ${ }^{* * *}$ for $P<0.001(0.1 \%)$

II, Basilisk and Xaraes) in Kenya dry lands as reported by Nguku et al. [42]. However, height may not be an important estimate on the expected biomass yield, as it has been clearly demonstrated that the shorter Eth. 13809 than Eth. 1377 had the best primary DM yield. This high DM yield of Eth. 13809 might be due to high number of tillers. 
Table 3 Mean chemical composition, yield of Bracheriea ecotypes

\begin{tabular}{|c|c|c|c|c|c|c|c|c|}
\hline \multirow{2}{*}{ Factor } & \multicolumn{8}{|c|}{ Parameters } \\
\hline & DM (\%) & DMY (t/ha) & Ash (\%) & $\mathrm{CP}(\%)$ & CPY (t/ha) & NDF (\%) & ADF (\%) & ADL (\%) \\
\hline \multicolumn{9}{|l|}{ Cultivars } \\
\hline Eth. 13726 & $36.71^{b}$ & $4.05^{b}$ & 10.87 & 11.23 & $0.38^{b}$ & 69.56 & $50.77^{\mathrm{a}}$ & $15.30^{\mathrm{a}}$ \\
\hline Eth. 13809 & $37.75^{\mathrm{a}}$ & $5.91^{\mathrm{a}}$ & 12.34 & 11.35 & $0.66^{\mathrm{a}}$ & 65.47 & $43.47^{b}$ & $11.13^{b}$ \\
\hline Eth. 1377 & $35.71^{c}$ & $5.09^{a b}$ & 11.27 & 10.94 & $0.52^{\mathrm{ab}}$ & 67.72 & $46.81^{b}$ & $13.31^{\mathrm{ab}}$ \\
\hline Overall mean & 36.72 & 5.02 & 11.49 & 11.17 & 0.52 & 67.59 & 47.02 & 13.24 \\
\hline Overall SE & 0.319 & 0.47 & 0.53 & 0.74 & 0.05 & 1.32 & 1.26 & 0.64 \\
\hline CV (\%) & 0.60 & 16.63 & 13.73 & 11.27 & 26.77 & 7.03 & 5.97 & 13.14 \\
\hline Sig & $* * *$ & $* *$ & NS & NS & $* *$ & NS & $* *$ & $* *$ \\
\hline \multicolumn{9}{|l|}{ Altitudes } \\
\hline Low & $37.77^{\mathrm{a}}$ & $5.93^{\mathrm{a}}$ & $12.22^{\mathrm{a}}$ & $12.59^{a}$ & $0.71^{\mathrm{a}}$ & 68.17 & 47.14 & 12.83 \\
\hline Mid & $36.61^{b}$ & $5.10^{\mathrm{ab}}$ & $10.09^{b}$ & $11.35^{\mathrm{a}}$ & $0.50^{\mathrm{b}}$ & 66.08 & 46.35 & 13.83 \\
\hline High & $35.79^{c}$ & $4.02^{b}$ & $12.17^{\mathrm{ab}}$ & $9.56^{b}$ & $0.35^{\mathrm{b}}$ & 68.51 & 47.56 & 13.08 \\
\hline Sig & $* * *$ & $* *$ & * & $* *$ & $* *$ & NS & NS & NS \\
\hline \multicolumn{9}{|l|}{ Harvesting dates } \\
\hline 60 & $35.49^{c}$ & $2.43^{c}$ & 12.20 & $15.00^{\mathrm{a}}$ & $0.37^{b}$ & $61.60^{b}$ & $40.65^{c}$ & $10.30^{c}$ \\
\hline 90 & $36.64^{b}$ & $5.29^{b}$ & 10.82 & $10.46^{b}$ & $0.58^{\mathrm{a}}$ & $67.08^{b}$ & $47.52^{b}$ & $13.40^{\mathrm{b}}$ \\
\hline 120 & $38.05^{a}$ & $7.33^{\mathrm{a}}$ & 11.47 & $8.05^{c}$ & $0.60^{\mathrm{a}}$ & $74.08^{\mathrm{a}}$ & $52.88^{a}$ & $16.04^{\mathrm{a}}$ \\
\hline Sig & $* * *$ & $* * *$ & NS & $* * *$ & * & $* *$ & $* * *$ & $* * *$ \\
\hline \multicolumn{9}{|l|}{$P$ value } \\
\hline $\mathrm{cul}^{*} \mathrm{al}$ & $* *$ & NS & $* *$ & $* *$ & $*$ & NS & NS & NS \\
\hline cul*hd & $* *$ & NS & NS & NS & NS & NS & NS & NS \\
\hline al*hd & NS & NS & NS & NS & NS & NS & NS & NS \\
\hline Interaction & $* * *$ & $* * *$ & $*$ & $* * *$ & * & NS & $* *$ & $*$ \\
\hline
\end{tabular}

$D M$ dry matter, $D M Y$ dry matter yield, $C P$ crude protein, $C P Y$ crude protein yield, NDF neutral detergent fiber, $A D F$ acid detergent fiber, $A D L$ acid detergent lignin Mean values followed by a different lowercase superscript letter in the same column are statistically significant at $P<0.05$

More tillers were reported for Eth. 13809 at 120 days (45.56) in low (35.77) and mid (35.07)-altitudes as shown in Table 1. Tillers density is an important attribute of grasses as it increases the chances of survival and amount of available forage $[28,51]$. Moreover, it is an indicator of resource use efficiency by the different grass species. The large numbers of tillers produced by some grass species allows them to attain maximum growth at an earlier age and recover faster after defoliation [28]. Tillering is also important in forage plants, because of its influence on leaf-area production and dry matter yield. Mean tiller number increased progressively for all ecotypes, and there were significant differences among the ecotypes $(P<0.05)$ as shown in Table 4 . The results in this study are similar to the findings by Mganga [35] and Machogu [32], where the tiller density differed among the local range grasses in Kenya.

The DM content increased with delayed harvesting because of decreased moisture content in leaves as the plants aged and became lignified. This result is in agreement with other studies $[4,8]$ for other types of grasses. The studies reported that the DM content of grasses increased with an increase in growth and development of plants and longer time to harvest. The higher dry matter yields at later stages of harvesting were to be expected as plants were taller, had more tillers per plant and more leaves per plant and leaf elongation and stem development. All these characteristics would contribute to increased photosynthetic activity and hence higher DM production. The highest total DM yield observed at the last harvest stage was in agreement with the work of Hare et al. [23], Njarui and Wandera [45] and Ondiko et al. [47] on wild Brachairia grasses at different countries; Tessema and Alemayehu [53], Leta et al. [29]; Asmare et al. [9] on cultivated grasses and Feyissa et al. [20] for natural pasture in Ethiopia. These researchers indicated that the time of harvesting had a high influences on dry matter yield. The highest yield of forage for the longest harvesting date could also be attributed to the favorable rainfall, temperature and available nutrient in the soil over the extended growing period of the grass in the study area. But, when compared with time taken until consumption, the age of the grasses at day 60 could be used by farmers 
Table 4 Overall morphological characteristics of three Brachiaria brizantha ecotypes on the effects of altitude and harvesting dates and their interactions

\begin{tabular}{|c|c|c|c|c|}
\hline \multirow[t]{2}{*}{ Factor } & \multicolumn{4}{|c|}{ Parameters } \\
\hline & $\mathrm{PH}(\mathrm{cm})$ & NTPP (counts) & NLPP (counts) & $\operatorname{LLPP}(\mathrm{cm})$ \\
\hline \multicolumn{5}{|l|}{ Ecotypes } \\
\hline Eth. 13726 & $51.07^{b}$ & $26.35^{b}$ & 4.74 & $17.29^{b}$ \\
\hline Eth. 13809 & $51.47^{b}$ & $33.52^{\mathrm{a}}$ & 4.36 & $20.10^{\mathrm{a}}$ \\
\hline Eth. 1377) & $58.73^{\mathrm{a}}$ & $29.38^{b}$ & 5.01 & $16.22^{b}$ \\
\hline Overall mean & 53.76 & 29.75 & 4.70 & 17.87 \\
\hline Overall SE & 3.33 & 2.03 & 0.20 & 0.78 \\
\hline CV (\%) & 8.65 & 8.15 & 11.44 & 5.25 \\
\hline Sig & $*$ & $* * *$ & NS & $* * *$ \\
\hline \multicolumn{5}{|l|}{ Altitudes } \\
\hline Low & $60.50^{\mathrm{a}}$ & $28.52^{b}$ & $4.96^{\mathrm{a}}$ & $18.93^{b}$ \\
\hline Mid & $57.62^{\mathrm{a}}$ & $33.62^{\mathrm{a}}$ & $5.04^{\mathrm{a}}$ & $20.22^{\mathrm{a}}$ \\
\hline High & $43.15^{b}$ & $27.12^{b}$ & $4.11^{\mathrm{b}}$ & $14.47^{c}$ \\
\hline Sig & $* * *$ & $* *$ & $*$ & $* * *$ \\
\hline \multicolumn{5}{|c|}{ Harvesting dates } \\
\hline 60 & $35.91^{c}$ & $20.52^{c}$ & $3.80^{c}$ & $14.93^{c}$ \\
\hline 90 & $56.20^{b}$ & $27.09^{b}$ & $4.57^{\mathrm{b}}$ & $17.93^{b}$ \\
\hline 120 & $69.17^{\mathrm{a}}$ & $41.63^{\mathrm{a}}$ & $5.74^{\mathrm{a}}$ & $20.76^{a}$ \\
\hline Sig & $* * *$ & $* * *$ & $* * *$ & $* * *$ \\
\hline \multicolumn{5}{|l|}{$P$ value } \\
\hline cul*al & NS & $* *$ & NS & * \\
\hline cul*hd & 0.0263 & NS & NS & NS \\
\hline al*hd & NS & NS & NS & NS \\
\hline Interaction & $* * *$ & $* * *$ & $*$ & $* * *$ \\
\hline
\end{tabular}

SE standard error, $C V$ coefficient of variation, $P H$ plant height, NTPP number of tillers per plant, LLPP leaf length per plant

Treatments means with different letters in a column are significantly different $(P<0.05)$ for altitudes and cutting age. NS for non-significant, * for $P<0.05(5 \%)$, ** for $P<0.01$ (1\%) and *** for $P<0.001(0.1 \%)$

for forage because the relative growth is high, soft and palatable with reduced lignin.

Overall, Eth. 13809 had highest dry matter yield $(5.91 \mathrm{t} /$ ha) which is followed by Eth. 1377 (5.09 t/ha). Variations in DM production across the ecotypes can be attributed to differences in growth rate and growth habit, which are mediated through the genotypic and phenotypic differences. This is a common phenomenon in grasses [35, 46]. In this study, the high primary DM yield by Eth. 13809 can be largely attributed to its large size leaves $(20.1 \mathrm{~cm}$ long) and tiller number (33.52) than the other two ecotypes. However, the leafy nature might be a disadvantage in dry areas where water supply is limited, as it facilitates rapid water loss through transpiration [48]. Grasses which yield the highest DM should be the most sought since they can supply the highest amount of forage to livestock. The average DMY of ecotypes (Eth. 13726 (4.05 t/ha), Eth. 13809 (5.91 t/ha and Eth. 1377 (5.09 t/ ha) were very high compared to $C$. ciliaris with $1.6 \mathrm{t} / \mathrm{ha}$ reported by Mutimura and Everson [39] and natural pasture (4.4 ton/ha) in Ethiopia [1].

Crude protein (CP) value of the three B. brizantha ecotypes (Eth. 13726 (16.33, 10.63 and 6.72\%), Eth. 13809 (13.87, 10.60 and 9.57\%) and Eth. 1377 (14.80, 10.15 and $7.86 \%)$ differed significantly $(P>0.05)$ among harvesting dates. As would be expected, the highest $\mathrm{CP}$ concentration was obtained at the earliest stage of harvesting, with values declining as harvesting was delayed. This result is in agreement to the findings by Njarui et al. [44] and Mutimura et al. [38] in Brachiaria grasses. Similarly, Bayble et al. [7] and Ansah et al. [5] reported a decreasing trend of $\mathrm{CP}$ with increase in harvesting age $(60>90>120$ days) for Napier grass. This is a growth dilution effect with increase in structural carbohydrate content of forage materials harvested at late maturity reducing the percentage of protein in the forage.

The higher CP Contents of Eth. 13809 and Eth. 1377 at low altitude and Eth. 13726 at mid-altitude were higher than one of the best Brachiaria hybrid cv. Mulato II reported by Mutimura and Everson [39] which had a CP of $11.1 \%$. The overall highest $\mathrm{CP}$ of the ecotypes was recorded in low land (12.59\%) compared to mid (11.35\%) and high land $(9.56 \%)$ which is contrary to those reported as high temperatures to have positive effect on quality of grasses [43]. This might be due to agro-ecological and management differences during the growth stages of ecotypes.

The CP content was generally high in all the Brachiaria grass ecotypes [Eth. 13726 (11.23\%), Eth. 13809 (11.35\%) and Eth. 1377(10.94\%)] compared with mean of (5.37.7\%) and (7-10\%) different Brachiaria grass cultivars reported by Ondiko et al. [47] and Nguku [41] in coastal lowlands of Kenya and in the semiarid region of eastern Kenya, respectively. Natural pasture, Rhodes grass, Tef straw, Maize stover and Finger millet straw were also found have very low $\mathrm{CP}$ value of $5.5,7.1,4.2,2.84$ and $4.12 \%$, respectively (Abebe et al. [1] and desho grass (8.35\%) [9]. Furthermore, the CP content was higher than the most Ethiopian dry forages and roughages which have a CP content of less than $9 \%$ [10], which is the level required for adequate microbial synthesis in the rumen [3]. Of the factors considered, the CP content at low altitude was higher $(12.59 \%)$ than at mid-altitude $(11.35 \%)$ and high altitude $(9.56 \%)$ which may have been associated with differences in temperature, precipitation and soil characteristics as reported by Daniel [17] where plant growth and quality were affected markedly by temperature and soil moisture conditions. Generally, all ecotypes in all altitudes including high altitude which is uncommon in other countries are highly palatable.

Forages with a CP content range of $9-12 \%$ are highly palatable [32]. Despite the reduction in CP percentage 
with time, crude protein yield (CPY) increased significantly as harvesting was delayed. Similar findings have been reported by Asmare et al. [9] for the desho grass species and by Melkie [34]. They recorded mean CPYs of Bana grass at 60, 90 and 120 days of age to have $0.47,0.91$ and $0.85 \mathrm{t} / \mathrm{ha}$, respectively. Obviously, decisions on the optimal time to harvest Brachiaria grass will depend on a compromise between yield and quality of forage.

As would be expected, NDF, ADF and ADL concentrations increased as harvesting date was delayed though there was no significant $(P<0.05)$ difference of NDF in Eth. 1377 and ADL in Eth. 13726 and Eth. 13809. Moreover, there was no significant $(P<0.05)$ difference in all ecotypes by altitude. The NDF content of forage varies widely, depending on species, maturity, and growing environment [12, 33, 40]. Therefore, each plant species presents a unique NDF-ADF ratio in the feed. For legumes, $<40 \%$ NDF content is classified as good quality forage, while $>50 \%$ [54] is considered as poor quality forage. For grasses, $<50 \%$ NDF is considered high quality and $>60 \%$ as low-quality forage. In this study, forage materials from all the grass ecotypes had $>60 \%$ NDF which may account for the low intake and digestibility. The higher fiber content in the Ecotype grasses, therefore, can be attributed to their phenological stage. Furthermore, increase in CF content is accompanied by increase in lignin content in forages. The forages, therefore, become less digestible because they are inaccessible to digestive enzymes [16]. The ash quantity of any feed is a positive indicator of the inorganic (minerals) content. Generally, most forage has ash content ranging from 3 to $12 \%$ (Linn and Martin [30]. All the three ecotypes investigated in this study were in the range shown by these authors.

\section{Conclusion}

Based on results, it can be concluded that the harvesting dates can affect the forage DM yield and nutritive values of Brachiaria grasses. Day 60 could be the optimal level for harvesting Brachiaria grass since the quality forage is high and yield is not compromised. The highest $\mathrm{CP}$ and lowest NDF and ADF concentrations were recorded in Eth13809. Thus, among the tested ecotype grasses Eth13809 showed great potential as a forage plant especially in low altitude since it has shown that it can grow under low rainfall maintaining high yields. Overall, Brachiaria grasses had a higher biomass yield and better chemical composition than the main feed resources of natural pasture and crop residues in the region. Therefore, it can be concluded that the studied Brachiaria grass ecotypes, especially Eth13809, have great potential as an alternative ruminant feed in all altitude areas in south Gondar. To fully utilize the potential of the studied Brachiaria grass ecotypes, further studies on agronomic and nutritional evaluation involving animal evaluation experiments are recommended.

\begin{abstract}
Abbreviations
ADF: acid detergent fiber; ADL: acid detergent lignin; AOAC: association of official analytical chemists; CP: crude protein; CPY: crude protein yield; CSA: central statistical agency; DM: dry matter; DMY: dry matter yield; EIAR: Ethiopian Institute of Agricultural Research; Eth: Ethiopia; FAO: Food and Agricultural Organization the United Nations; GLM: general linear model; LLPP: leaf length per plant; NDF: neutral detergent fiber; NLPP: number of leaf per plant; NTPP: number of tillers per plant; PH: plant height; OM: organic matter; SAS: statistical analysis system.
\end{abstract}

\section{Authors' contributions}

WA contributed in research proposal writing, data collection, data analysis, data interpretation and article writing. BA, AT and BA contributed in research data collection, data analysis, data interpretation and article writing. All authors read and approved the final manuscript.

\section{Authors' information}

Adnew is a candidate of PhD at Bahir Dar University, College of Sciences in Biology Department. Berhanu Abraha Tsegay (PhD) is an Associate professor of Biology, Bahir Dar University, Plant Biology, currently teaching at graduate program and conducting research on plant ecophysiology and Ethnobotany. Tassew (PhD) is an Associate professor of animal production, currently teaching and conducting research in the area of animal feeds and feeding, animal production and productivity improvement in Ethiopia. Asmare (PhD) is an Assistant Professor of Animal Feeds and Nutrition, currently teaching and conducting research in the area of animal feeds and feeding, animal production and productivity improvement in Ethiopia.

\section{Author details \\ ${ }^{1}$ Department of Biology, College of Science, Bahir Dar University, P. O. Box 76, Bahir Dar, Ethiopia. ${ }^{2}$ Department of Animal Production and Technology, College of Agriculture and Environmental Sciences, Bahir Dar University, P.O. Box 5501, Bahir Dar, Ethiopia.}

\section{Acknowledgements}

The first author is grateful to Bahir Dar University for funding the research work. He also extends his thanks to Fogera National Rice Research Institute, Farta and Tach Gayint district agricultural offices for their permission to use the respective experimental sites. He also appreciates the contribution of Mr. Bamlaku Getie, Mr. Getachew Molla and Mr Yilak Hulgezie for their assistance during field data collection.

\section{Competing interests \\ All authors declare that they have no competing interests.}

\section{Availability of supporting data}

The datasets used and/or analyzed during the current study available from the corresponding author on reasonable request.

\section{Consent for publication}

Not applicable.

Ethical approval and consent to participate

Not applicable.

Funding

Bahir Dar University, College of Sciences.

\section{Publisher's Note}

Springer Nature remains neutral with regard to jurisdictional claims in published maps and institutional affiliations. 
Received: 21 October 2018 Accepted: 23 November 2018 Published online: 12 December 2018

\section{References}

1. Abebe Y, Tafere M, Dagnew S, Tolla M, Gebre-Selassie Y et al. Best fit practice manual for Rhodes grass (Chloris gayana) production. BDUCASCAPE, 2015;working paper 10.

2. Adnew W, Tsegay BA, Tassew A, Asmare B. Assessments of farmers perception and utilization status of Brachiaria grass in selected areas of Ethiopia. Biodiversitas. 2018;19(3):951-62. https://doi.org/10.13057/biodi v/d190326.

3. Agricultural Research Council. The nutrient requirements of ruminants livestock (Supp. 1). Farnham Royal, UK: Commonwealth Agricultural Bureaux; 1980. p. 351

4. Alemu B, Melaku S, Prasad NK. Effects of varying seed proportions and harvesting stages on biological compatibility and forage yield of oats (Avena sativa L.) and vetch (Vicia villosa R.) mixtures. Livest Res Rural Dev. 2007;19:1e9.

5. Ansah T, Osafo ELK, Hansen HH. Herbage yield and chemical composition of four varieties of Napier (Pennisetum purpureum) grass harvested at three different days after planting. Agric Biol J N Am. 2010;1(5):923-9. https://doi.org/10.5251/abjna.2010.1.5.923.929.

6. Arango J, Moreta D, Núñez J, Hartmann K, Domínguez M, Ishitani M, Miles J, Subbarao G, Peters M, Rao I. Developing methods to evaluate phenotypic variability in biological nitrification inhibition (BNI) capacity of Brachiaria grasses. Trop Grassl Forrajes Trop. 2014;2:6-8.

7. Bayble T, Melaku S, Prasad NK. Effects of cutting dates on nutritive value of Napier (Pennisetum purpureum) grass planted sole and in association with Desmodium (Desmodium intortum) or Lablab (Lablab purpureus). Livestock Research for Rural Development 2007-19, article \#11. www.Irrd. org//rrd19/1/bayb19011.htm. Accessed 11 May 2016.

8. Berihun M. Effect of planting patterns and harvesting days on yield and quality of Bana Grass [Pennisetum purpureum (L.) Pennisetum americanum (L.)] (Master thesis). School of Graduates of Haramya University, 2005, Harar, Ethiopia.

9. Asmare B, Solomon D, Taye T, Firew T, Aynalem H, Jane W. Effects of altitude and harvesting dates on morphological characteristics, yield and nutritive value of desho grass (Pennisetum pedicellatum Trin.) in Ethiopia. Agric Nat Resour. 2017;51:148-53.

10. Bediye S, Sileshi Z. The composition of Ethiopian feedstuffs, Research Report No. 6. Addis Ababa, Ethiopia: Institute of Agricultural Research (IAR); 1989. pp 33

11. Bogdan AV. Herbage plants at the grassland research station, Kitale, Kenya. East Afr Agric For J. 1955;20:151-65.

12. Buxton DR, Fales SL. Plant environment and quality. In: Fahey Jr GC, editor. Forage quality, evaluation and utilization. Madison: ASA-CSSASSA; 2004. p. 155-99.

13. CSB (Climate-Smart Brachiaria Program). CSB annual review meeting. KALRO (Kenya Agricultural and Livestock Research Organization), Embu, Kenya 2016. goo.gl/VbzJ4D.

14. Central Statistical Agency (CSA), Agricultural Sample Survey. Livestock and livestock characteristics (private peasant holdings) (Addis Ababa Ethiopia). Stat Bull. 2017:585(2):33-5.

15. CIAT. Pastures for the tropical lowlands. Cali: CIAT; 1992.

16. Crowder LV, Chheda MR. Tropical grassland husbandry. London: Longman; 1982.

17. Daniel K. Effect of nitrogen application and stage of development on yield and nutritive value of Rhodes grass (Chloris gayana). Ethiop J Agric Sci. 1996;15:86-101

18. EIAR. Livestock research strategies (2016-2030): feeds and nutrition, rangelands and animals health. Addis Ababa: Ethiopia Institute of Agricultural Research; 2017.

19. Jirata M, Grey S, Kilawe E. Ethiopia climate-smart agriculture scoping study. Addis Ababa, Ethiopia: FAO; 2016. http://www.fao.org/publications

20. Feyissa F, Shiv P, Getnet A, Seyoum B, Getu K, Aemiro K, Gezahenge K. Dynamics in nutritional characteristics of natural hays as affected by harvesting stage, storage method and storage duration in the cooler tropical highlands. Afr J Agric Res. 2014;9:3233-44.
21. Gelayenew B, Nurfeta A, Assefa G, Asebe G. Assessment of livestock feed resources in the farming systems of mixed and shifting cultivation, Gambella Regional State, Southwestern Ethiopia. Glob J Sci Front Res. 2016;XVI(V):1

22. Ghimire SR, Njarui D, Mutimura M, Cardoso JA, Johnson L, Gichangi $E$, Teasdale S, Odokonyero K, Caradus JR, Rao IM, Djikeng A. Climate-smart Brachiaria for improving livestock production in East Africa: Emerging opportunities. In: Vijay D, Srivastava MK, Gupta CK, Malaviya DR, Roy MM, Mahanta SK, Singh JB, Maity A, Ghosh PK, editors. Proceedings of the XXIII international grassland congress, New Delhi, India, 2015. 20-24 November 2015. p. 361-370. hdl.handle.net/10568/69364.

23. Hare MD, Phengphet S, Songsiri T, Sutin N, Stern E. Effect of cutting interval on yield and quality of three Brachiaria hybrids in Thailand. Trop Grassl Forrajes Trop. 2013;1:84-6.

24. Huhtanen P, Nousiainen J, Rinne M. Recent developments in forage evaluation with special reference to practical applications. Agric Food Sci. 2006;15:293-323

25. Jank L, Barrios SC, do Valle CB, Simeao RM, Alves GF. The value of improved pastures to Brazilian beef production. Crop Pasture Sci. 2014;65:1132. https://doi.org/10.1071/cp13319.

26. Jančík F, Koukolová V, Kubelková P, Čermák B. Effects of grass species on ruminal degradability of silages and prediction of dry matter effective degradability. Czech J Anim Sci. 2009;54:315-23.

27. Kluthcouski J, de Oliveira I, Yokoyama L, Dutra L, Portes TDA, da Silva A, Pinheiro BDS, Ferreira E, de Castro EDM, Guimarães CM, Gomide JDC, Balbino LC. The Barreirão system: recovering and renewing degraded pastures with annual crops. In: Guimarães EP, Sanz JI, Rao I, Amézquita MC, Amézquita E, Thomas RJ, editors. Agropastoral systems for the tropical savannas of Latin America 2004, vol 338. Centro Internacional de Agricultura Tropical (CIAT), Cali, Colombia.

28. Laidlaw A. The relationship between tiller appearance in spring and contribution of dry-matter yield in perennial ryegrass (Loliumperenne L.) cultivars differing in heading date. Grass Forage Sci. 2005;60:200-9.

29. Leta G, Duncan A, Abdena A. Desho grass (Pennisetum pedicellatum) for livestock feed, grazing land and soil and water management on smallscale farms. In: NBDC Brief 11, International Livestock Research Institute (ILRI), Nairobi, Kenya (2013).

30. Linn JG, Martin NP. Forage quality tests and interpretations; 1999 (access online).

31. Maass BL, Midega AO, Mutimura M, Rahetlah VB, Salgado P, Kabirizi JM, Khan ZR, Ghimire S, Rao IM, Homecoming of brachiaria: improved hybrids prove useful for African animal agriculture. East Africa Agric Fo J. 2015;81:71-8

32. Machogu C. A comparative study of the productivity of brachiaria hybrid CV. mulato II and native pasture species in semi-arid rangelands of Kenya: M.Sc., Thesis paper, Nairobi, Kenya;2013.

33. Mahyuddin P. Chemical composition of leaf and stem of tropical grasses at different stage of growth. J ProduksiTernak. 2007;9(3):153-9.

34. Melkie B. Effect of planting patterns and harvesting days on yield and quality of Bana grass [Pennisetum purpureum $\times$ Pennisetum americanum]. M.Sc. Thesis, 2005. Haramaya University, Harar, Ethiopia.

35. Mganga K. (2009) Impact of grass reseeding technology on rehabilitation of degraded rangelands: a case study of Kibwezi district, Kenya. University of Nairobi, M.Sc. Thesis, Nairobi, Kenya.

36. Moreta DE, Arango J, Sotelo M, Vergara D, Rincón A, Ishitani N, Castro A, Miles J, Peters M, Tohme J, Subbarao GV, Rao IM. Biological nitrification inhibition (BNI) in Brachiaria pastures: A novel strategy to improve ecoefficiency of crop-livestock systems and to mitigate climate change. Trop Grassl Forrajes Trop. 2014;2:88-91.

37. Mureithi JG, Djikeng A. Overview of the climate-smart Brachiaria grass programme. In: Njarui DMG, Gichangi EM, Ghimire SR, Muinga RW, editors. Climate-smart Brachiaria grasses for improving livestock production in East Africa: Kenya experience: Proceedings of a workshop, Naivasha, Kenya, 2016;14-15 September 2016. Kenya Agricultural and Livestock Research Organization, Nairobi, Kenya.

38. Mutimura M, Ebong C, Rao IM, Nsahlai IV. Effect of cutting time on agronomic and nutritional characteristics of nine commercial cultivars of Brachiaria grass compared with Napier grass during establishment under semi-arid conditions in Rwanda. Afr J Agric Res. 2017;12(35):2692-703. 
39. Mutimura M, Everson T. On-farm evaluation of improved Brachiaria grasses in low rainfall and aluminium toxicity prone areas of Rwanda. Int J Biodivers Conserv Biol. 2012;4:137-54.

40. Nelson CJ, Moser LE. Plant factors affecting forage quality. In: Fahey Jr GC, editor. Forage quality, evaluation and utilization. Madison: ASA-CSSASSSA; 1994. p. 115-54

41. Nguku S. An evaluation of brachiaria grass cultivars productivity in semi arid Kenya. MSc. Thesis, South Eastern Kenya University, Kenya; 2015

42. Nguku S, Musimba N, Njarui D, Mwobobia R, Kaindi E. Effects of acid scarification on germination of the genus Brachiaria grass Cultivars. Int J Sci Res Innov Technol. 2016;3:45-50.

43. Njarui DMG, Gatheru M, Mwangi DM, Keya GA. Persistence and productivity of selected Guinea grass ecotypes in semiarid tropical Kenya. Grassl Sci. 2015;61:142-52

44. Njarui DMG, Gichangi E, Gatheru M, Nyambati EM, Ondiko CN, Njunie MN, Ndungu KW, Kiiya WW, Kute CAO, Ayako W. A comparative analysis of livestock farming in smallholder mixed crop-livestock systems in Kenya: 1. Livestock inventory and management. Livestock Research for Rural Development, 2016; 28, Article \#066.

45. Njarui DMG, Wandera FP. Effects of cutting frequency on productivity of five selected herbaceous legumes and five grasses in semi-arid tropical Kenya. Trop Grassl. 2004;38:158-66.

46. Ogillo BP. Evaluating performance of range grasses under different micro catchments and financial returns from reseeding in Southern Kenya. Nairobi, Kenya: Unpublished M.Sc. Thesis; University of Nairobi; 2010.

47. Ondiko CN, Njunie MN, Njarui MG, Auma E, Ngode L. Effect of cutting frequency on forage production and nutritive value of Brachiaria grass cultivars in coastal lowlands of Kenya. In: Njarui DMG, Gichangi EM, Ghimire
SR, Muinga RW, editors. Climate smart brachiaria grasses for improving livestock production in East Africa-Kenya experience. Proceedings of the workshop held in Naivasha, Kenya, 14-15 September 2016, Nairobi, Kenya; 2016. p. 271

48. Pratt and Gwynne. Rangeland management and ecology in East Africa. London: Hodder and Stroughton; 1977.

49. Rodrigues RC, Sousa TVR, Melo MAA, Araújo JS, Lana RP, Costa CS, Oliveira MO, Parente MOM, Sampaio IBM. Agronomic, morphogenic and structural characteristics of tropical forage grasses in northeast Brazil. Trop Grassl Forrajes Trop. 2014;2:214-22.

50. Schiek B, González C, Mwendia S, Steven D. Prager. Got forages? Understanding potential returns on investment in Brachiaria spp. for dairy producers in Eastern Africa. Trop Grassl Forrajes Trop. 2018;6(3):117-133. https://doi.org/10.17138/tgft(6)117-133.

51. Skerman PJ, Riveros F. Tropical grasses. FAO Plant Production and Protection Series No. 23. Rome, Italy; Food and Agriculture Organisation, 1990.

52. Steinfeld H, Gerber P, Wassenaar T, Castel V, Rosales M, de Haan C. Livestock's long shadow: environmental issues and options. Food and Agriculture Organization of the United Nations, Rome, 2006. http://www. fao.org/docrep/fao/010/a0701e/a0701e00.pdf.

53. Tessema K, Alemayehu M. Management of Napier grass (Pennisetum purpureum (L) Schumach) for high yield and nutritional quality in Ethiopia: a review. Ethiop J Anim Prod. 2010;10:73-94.

54. Van Saun RJ. Determining forage quality: understanding feed analysis. Lamalink.com. 2006;3(8):18-9.

55. Van Soest PJ, Robertson JB. Analysis of forage and fibrous food. In: A laboratory manual for animal science, vol 613. Ithaca, NY, USA: Cornell University; 2015
Ready to submit your research? Choose BMC and benefit from:

- fast, convenient online submission

- thorough peer review by experienced researchers in your field

- rapid publication on acceptance

- support for research data, including large and complex data types

- gold Open Access which fosters wider collaboration and increased citations

- maximum visibility for your research: over 100M website views per year

At BMC, research is always in progress.

Learn more biomedcentral.com/submissions 